\author{
Samir Sattarov* \\ Azerbejdżańska Narodowa Akademia Nauk \\ https://orcid.org/0000-0001-6380-0230
}

\title{
Cenzura rosyjska wobec twórczości „polskich poetów kaukaskich"
}

Streszczenie: W niniejszym artykule autor pisze o cenzurze rosyjskiej wobec twórczości „polskich poetów kaukaskich”. Ich utwory, ze względu na przeszłość polityczną samych poetów, podlegały surowej cenzurze w Imperium Rosyjskim. Mimo to, autorzy w swoich utworach wyrażali często swój sprzeciw antykolonialny i antyrządowy - w sposób jawny i ukryty. Cenzura rosyjska „oczyszczała” nagminnie utwory „polskich poetów kaukaskich” ze „szkodliwych dla władzy informacji i poglądów”. Szczególnie „niebezpieczne” teksty zakazywano drukować. Dość łatwo jednak przechodziły cenzurę utwory niezawierające poglądów politycznych. W artykule autor zwraca uwagę na to, że kontakty osobiste autorów odgrywały szczególną rolę dla procesu cenzury tekstów.

Słowa-klucze: cenzura, Kaukaz, Imperium Rosyjskie, XIX wiek, „polscy poeci kaukascy", zesłanie, literatura.

Samir Sattarov - dr, socjolog i filolog; pracownik Instytutu Literatury im. Nizami Gandżawi Azerbejdżańskiej Narodowej Akademii Nauk w Baku. Autor rozprawy Wzorce polskości-analiza ciagtości i zmian. (Przypadek Stowarzyszenia „Polonia-Azerbejdżan” w latach 2003-2014) (Warszawa 2014).Email: samir@op.pl 


\section{Russian censorship in the context of the works of "Polish Cau- casian poets"}

Summary: In this article, the author writes about Russian censorship in the context of the works of "Polish Caucasian poets". Their writings, due to the political past of the poets, were subject to severe censorship in the Russian Empire. However, the authors often explicitly and implicitly expressed their anti-colonial and anti-government attitude. Russian censorship often "purified" the texts of "Polish Caucasian poets" from "the information and views harmful to the authorities". Especially "dangerous" works were forbidden for publishing. The works that did not express political views easily passed through censorship. In the article, the author pays attentions also to the fact that personal contacts also played an important role in the passing through censorship. This is why even the potentially dangerous texts written by Polish exiles in the Caucasus could be published.

Key words: censorship, the Caucasus, Russian Empire, 19th century, "Polish Caucasian poets", exile, literature.

Wiek XIX w Imperium Rosyjskim to okres burzliwych wydarzeń i sporów politycznych oraz społecznych. W skład Imperium Rosyjskiego wchodziły wówczas zarówno Polska, jak i Azerbejdżan. W tym okresie w Imperium Rosyjskim szerzyły się idee związane z wolnością, walką o niepodległość podbitych przez Rosję krajów, a po inwazji Napoleona na Rosję w 1812 roku do wyżej wymienionych idei doszły też te związane ze swobodą jednostki, walką o zniesienie pańszczyzny i absolutyzmu. Progresywni autorzy tego okresu w utworach i publikacjach często odzwierciedlali wyżej wymienione idee.

W takiej sytuacji, aby zapobiec rozpowszechnieniu się ,,szkodliwych dla Imperium Rosyjskiego" idei, państwo zwiększyło zakres działania i kompetencje cenzury, która była instrumentem kontroli wydawanych w kraju i sprowadzanych z zagranicy książek i innych publikacji.

W ten sposób 9 czerwca 1804 roku Aleksander I zatwierdził pierwszą w Imperium Rosyjskim „Ustawę o cenzurze”. Kontrolę powierzono komitetom 
cenzuralnym, w skład których wchodzili profesorzy i magistrzy uniwersytetów kierowanych przez Główny Zarząd Szkół Ministerstwa Oświaty Narodowej. Wyjątek stanowiła literatura religijna, której cenzurą zajmował się Synod. W ten sposób cenzura literatury świeckiej znajdowała się pod jurysdykcją Ministerstwa Oświaty Narodowej.

Już w 1810 roku cenzurą literacką zajmowało się Ministerstwo Policji, a po jego likwidacji w 1819 roku funkcje cenzury przejęło Ministerstwo Spraw Wewnętrznych. W 1826 roku, po wybuchu powstania Dekabrystów, minister oświaty A. Sziszkow wprowadził nową „Ustawę o cenzurze”, zgodnie z którą najwyższą instancją cenzuralną był Najwyższy Komitet Cenzury, który składał się z ministrów: oświaty narodowej, spraw wewnętrznych i zagranicznych. Podległe mu były Komitety Cenzury w Petersburgu, Moskwie, Derpcie i Wilnie. 22 kwietnia 1828 roku przyjęta została trzecia, łagodniejsza „Ustawa o cenzurze”. Kolejna ustawa podporządkowała cenzurę Ministerstwu Oświaty Narodowej, gdzie utworzono Główny Zarząd Cenzury ${ }^{1}$.

W niniejszym artykule chciałbym skupić swoją uwagę na cenzurze rosyjskiej wobec utworów pisanych przez ,polskich poetów kaukaskich”, wydawanych tak w Imperium Rosyjskim w XIX wieku, jak poza jego granicami.

Do grupy „polskich poetów kaukaskich” należeli polscy literaci zesłani na Kaukaz przez rząd carski w XIX wieku za udział w tajnych stowarzyszeniach (Władysław Strzelnicki, Konstanty Zach, Mateusz Gralewski i in.), ruchach spiskowych proklamujących idee wolności i niepodległości Polski (Ksawery Pietraszkiewicz, Michał Butowt-Andrzejkowicz, Władysław Jurkowski, Jan Załęski, Arystarch Sosnowski, Hugo Korsak, Franciszek Sawicz, Stanisław Winnicki i in.), a także w powstaniach narodowowyzwoleńczych w Królestwie Polskim (Leon Janiszewski, Leon Gerszewski, Marian Ciepliński, Hipolit Jaworski, Stanisław Pilat i in.). Byli też tacy, których zesłano na Kaukaz za ich twórczość literacką. Na przykład, Tadeusz Łada-Zabłocki został zesłany na Kaukaz za antyrządowy wiersz, w którym pisał:

Ledwie nocy schodzi cień

Ledwie nowy wita dzień

1 Ц. Дондоков, Я. Понуровский, Цензура печати в Российской империи, „Вестник ЧИтГУ 2011”, №6 (73), стр.19; B. Mucha, Dzieje cenzury w Rosji, Łódź 1994, s. 82-87, 93-94, 111. 
Już ukazów lata strach,

Niewinnemu grozi knut,

I w rekruty idzie Lach

A [z] Sybiru wściekły pies

Szydzi jeszcze z naszych łez.

Piekłem dla nas carów tron,

Na nim teraz siedzi czart

Szubienicy ledwie wart.

Zemsta, bracia, albo zgon! ${ }^{2}$

Wiersz ten później nie wszedł do zbioru Poezje Tadeusza Łady-Zabłockiego (Poezje pierwszego okresu), został usunięty przez autora najprawdopodobniej ze względu na cenzurę.

Utwory ,polskich poetów kaukaskich” pisane na Kaukazie podczas zsyłki często publikowane były w Petersburgu (Poezje Tadeusza Łady-Zabłockiego), Warszawie (Leon Janiszewski, Michał Butowt-Andrzejkowicz, Jan Załęski), Żytomierzu (Władysław Strzelnicki), Wilnie (Michał Butowt Andrzejkowicz) i innych miastach Imperium Rosyjskiego. Ze względu na przeszłość powstańczą czy też przeszłą antyrządową działalność literacką , polskich poetów kaukaskich" ich utwory podlegały surowej cenzurze. Na Kaukazie oprócz cenzury literackiej działała również cenzura wojenna, która zwracała uwagę na teksty zawierające szczegóły bitew z narodami kaukaskimi oraz cenzura kaukaska, której zadaniem było niedopuszczenie drukowania utworów zawierających teksty zgodne z interesami państw trzecich (przeważnie Persji i Turcji, ale też krajów europejskich) $)^{3}$. Jednak nie bacząc na to, autorzy często w sposób jawny i ukryty wyrażali swój sprzeciw antykolonialny i antyrządowy w swoich utworach.

Na przykład Tadeusz Łada-Zabłocki, w wierszu Zdrowie Dymitra Demidowa porównuje Demidowa do Prometeusza niesprawiedliwie przykutego do

2 Д. Прокофьева, Об одном стихотворении Тадеуша Лады-Заблоикого, „Советское славяноведение" 1976, $\mathrm{nr}$ 4, s. 91.

3 Trzeba dodać że, za czasów PRL utwory polskich autorów emigracyjnych nie były publikowane w Polsce bez względu na temat, choć zdarzały się też wyjątki, np. w 1956 roku w Krakowie wydany był zbiór opowiadań Witolda Gombrowicza pt. Bakakaj; w 1980 w Warszawie były wydane Wiersze wybrane, a w 1981 roku Poezje wybrane Czesława Miłosza. 
gór kaukaskich, który - nie zwracając uwagi na męki dostarczane mu przez ówczesną władzę - z uśmiechem znosił burze i wyzywał świat do walki"

\author{
Jak ów Prometeusz pochopny \\ Którego Jowisza gniew chłostał, \\ W męczarniach katuszy okropnej \\ Jak skała niezgiętym pozostał; \\ Choć nad nim grom w czarnej przetaczał się chmurze \\ Świat wyzwał do walki, z uśmiechem zniósł burze 5 .
}

Ze względu na surową cenzurę stosowaną wobec twórczości „polskich poetów kaukaskich" (którzy zesłani byli na Kaukaz za swoją działalność rewolucyjną i antyrządową) i jej konsekwencjami, które ewentualnie mogłyby jeszcze bardziej pogorszyć ich sytuację, część „polskich poetów kaukaskich” starała się w swoich utworach omijać drażniące cenzurę tematy.

Na przykład Leon Janiszewski po przybyciu na Kaukaz skupił się na działalności teatralnej, pisał o historii chrześcijaństwa w Gruzji, często opisywał w swoich utworach krajobrazy kaukaskie. Wśród utworów, które łatwo przeszły przez cenzurę rosyjską, są Szkice Kaukazu i Poezje Władysława Strzelnickiego, przetłumaczone przez Konstantego Zacha Pieśni Tatarów ${ }^{6}$ i Persów, wiersze liryczne Juliusza Muczlera i in. We wszystkich wyżej wymienionych utworach brak idei antyrządowych. Ksawery Pietraszkiewicz pod wpływem Sonetów krymskich Adama Mickiewicza napisał Sonety kaukaskie, zarysowując taniec góralski „lezginka” czy też opisując w sonecie Noc w Gombori przyrodę jednej z wiosek, położonych w górach. W prozatorskich wspomnieniach Pietraszkiewicz opisuję groźną walkę człowieka z naturą ${ }^{7}$. Większość tekstów Pietraszkiewicza jednak nie została nigdy opublikowana.

4 S. Sattarov, Orient w twórczości „,polskich poetów kaukaskich” (na przykładzie twórczości Tadeusza Łady-Zabłockiego, Władysława Strzelnickiego, Michała Butowta-Andrzejkowicza), „Tematy i Konteksty" 2019, nr 9 (14), s. 316.

5 T. Łada-Zabłocki, Zdrowie Dymitra Demidowa improwizacja, [w:] Poezje Tadeusza LadyZabłockiego, Drukarnia Karola Kraja, Petersburg, 1843, s.160.

6 Tatarami kaukaskimi w XIX wieku nazywano w Rosji Azerów.

7 M. Filina, D. Ossowska, Losy Polaków na Kaukazie, Wydawnictwo „Universal”, Tbilisi 2015, s. 68-69. 
Trzeba też dodać, że zakorzenione w umysłach polskich zesłańców dążenie do niepodległości i idee związane $\mathrm{z}$ wolnością powodowały dalszą kontynuację walki z przeprowadzaną przez rząd carski polityką.

Jak wspomnieliśmy wyżej, Leon Janiszewski w swojej twórczości, starał się unikać tematów politycznych, jednak nie patrząc na to, będąc pod silnym wrażeniem Jeńca kaukaskiego Aleksandra Puszkina w 1851 roku przetłumaczył ten utwór na język polski. Tekst został wysłany do warszawskiego „Pamiętnika Naukowo-Literackiego". Utwór ten został opublikowany w siódmym numerze wyżej wymienionego czasopisma bez zgody cenzury rosyjskiej. Wskutek czego redaktor pisma Romuald Podbereski (który miał bardzo bliskie kontakty z kaukaskimi zesłańcami) został aresztowany przez policję carską. Na liście poszukiwanych znalazł się i Leon Janiszewski, ale szukano go w kraju. Pobyt na zesłaniu, w pewnym sensie, uratował go od powtórnego wygnania.

Szkice Kaukazu Michała Butowta-Andrzejkowicza zawierają bogaty materiał geograficzno-etnograficzny o Kaukazie. Jak słusznie zaznacza Maria Filita i Danuta Ossowska w swoim opracowaniu pod tytułem Losy Polaków na Kaukazie:

...trudno uwierzyć, żeby człowiek, który brał udział w krwawych rozprawach z Szamilem, w ekspedycjach na Dargo, Czyrkiej, Akuszę, miał do powiedzenia niewiele więcej ponad to, że bitwy te miały miejsce. Pomija też fakty i szczegóły dotyczące kręgu prywatnych spraw. Tekst wyraźnie robi wrażenie mocno pod tym względem „oczyszczonego8.

Sam autor Szkiców Kaukazu w liście z Petersburga z dnia 2 marca 1856 roku do Józefa Ignacego Kraszewskiego pisał:

Poznałem się tu niedawno z Przecławskim, któren mi mówił, że w Cesarstwie od kilku lat nadzwyczajnie trudno drukować o Kaukazie, bo oprócz cenzury zwyczajnej, kaukaskie rzeczy muszą jeszcze przechodzić przez dwie inne cenzury, przez wojenną i kaukaską, w której żaden z członków nie umie po polsku"9. 2015, s.71.

M. Filina, D. Ossowska, Losy Polaków na Kaukazie, Wydawnictwo „Universal”, Tbilisi

9 List Andrzejkowicza do J. I. Kraszewskiego, rkps BJ, sygn. 6460/IV. 
Szkice Kaukazu wydane zostały w Warszawie dopiero w 1859 roku, po roku od oddania utworu do cenzurowania w Wilnie. Prawdopodobnie tekst by „oczyszczony” zgodnie ze wskazówkami cenzury rosyjskiej.

Nawet twórczość takiej uprzywilejowanej osoby jak Wojciech Potocki nie uniknęła cenzury rosyjskiej. Przebywał na Kaukazie nie jako zesłaniec, a jako oficer do specjalnych poruczeń i adiutant generała Grigorija Władimirowicza Rosena, który dobrze znał rodzinę Potockiego. Wymienić można chociażby wiersz Potockiego Na śmierć Władystawa Strzelnickiego, z którego został wycięty przez cenzurę rosyjską fragment nawiązujący do wygnańczego losu' ${ }^{10}$ :

On poszedł dokąd idą ziomków naszych krocie Skąd rzadko kto powrotem matkę uweselił.

Władysław Jurkowski podczas pobytu na Kaukazie napisał między innymi Wspomnienia Kaukazu, które ukazują brutalną prawdę o wojnie prowadzonej w tamtym czasie przez Rosję na Kaukazie. Wspomnienia Kaukazu nie były jednak opublikowane i dotychczas pozostają w rękopisie.

Najbardziej radykalny z ,polskich poetów kaukaskich” pod względem wyznawanych poglądów społecznych Jan Załęski ze względu na cenzurę nigdy nie publikował swoich utworów pod własnym nazwiskiem. Podpisywał się zawsze inicjałami J.Z. Wśród jego prac o Kaukazie można wymienić: Rys życia obozowego, Wyjątki z pamiętników, Wieczór na Kaukazie, Wspomnienia z podróży po Kaukazie.

Marcin Szymanowski zajmował się tłumaczeniem utworów pisarzy i poetów rosyjskich i ukraińskich (Puszkina, Gogola, Odojewskiego, Szewczenki, Mikołaja Pawłowa). Próbował też własnej twórczości, napisał pokaźny zbiór jego tekstów poetyckich, który jednak został skonfiskowany podczas aresztowania. Napisał również dzieło pod tytułem Zarysy Kaukazu. W liście z 24 czerwca 1852 roku do Zawadzkiego Szmanowski pisał:

Pierwszy tom już wykończony, zawiera on wiadomości geograficzne i historyczny rozwój miurydyzmu - o ile w pierwszym dziale znajomię czytelników z miejscowością 
i szczegółami teatru wojny, o tyle w drugim przedstawiłem w krótkości przeszłość górali, a obszerniej główną sprężynę wojny świętej - miurydyzm i życiorys Imama Szamila wraz z poglądem ogólnym na dzisiejszy stan gór i charakterystyczne cechy plemion przyznających władzę Szamila. Do pierwszego tomu należy szczegółowa mapa i kilka rysunków z natury, dających pojęcie o ubiorach i miejscowości. Następne tomy mają mieścić obrazki z życia żołnierza i szkic działań przeciw góralom w wyprawach wojsk Cesarsko Rosyjskich do roku 1850. Ponieważ jako pomocnicze źródła służyły mi wiadomości o Kaukazie znane powszechnie w literaturze rosyjskiej - cenzura w dziełku moim nie znajdzie nic do wykreślenia"11.

Jednak dzieła nie udało się wydać. Po śmierci poety wszystkie materiały wyżej wymienionego dzieła zostały rozproszone.

Mateusz Gralewski po zsyłce kaukaskiej osiedlił się i mieszkał do 1864 roku w Warszawie. Po stłumieniu Powstania styczniowego wyjechał za granicę. W 1865 roku wydał w Lipsku pracę pod tytułem Myśli o naszych działaniach w kraju i za granica. W 1877 we Lwowie wydał swoje dzieło pod tytułem Kaukaz. Wspomnienia z dwunastoletniej niewoli. Opisanie kraju. Ludność. Zwyczaje i obyczaje. Na emigracji wydawał założone wraz z Karolem Mikoszewskim czasopismo „Braterstwo” (1864-1865), propagujące patriotyzm, a skierowane do chłopów. Ze względu na zakaz cenzury rosyjskiej tego pisma nie można było przywozić do kraju. Jednak trzeba zaznaczyć, że pismo cieszyło się powodzeniem wśród emigrantów polskich w Europie. Wkrótce Gralewski wraca do kraju i do końca życia mieszka we Lwowie. W 1875 roku wydaje swoje dzieło pod tytułem Polacy na Kaukazie. Książka napisana we Francji dopiero po dziesięciu latach wydana została we Lwowie. Ze względu na wyrażane w tym dziele poglądy polityczne nie miało żadnej szansy na druk w Imperium Rosyjskim. Tylko dzięki wsparciu Adama Dominika Bartoszewicza udało się uniknąć cenzury. Najpoważniejszym dziełem Gralewskiego jest jednak jego praca pod tytułem Kaukaz. Autor opisuje tu wydarzenia z perspektywy obserwatora z ostrą krytyką caratu.

Jak widać, w pewnych sytuacjach znajomości osobiste pozwalały uniknąć wnikliwej cenzury. Niektóre wiersze, które weszły w zbiór Poezji Tadeusza

11 Listy Marcina Szymanowskiego do Adama Zawadzkiego, Lietuvos Valstybes Istorijos Archyvas, zespół 1135, nr inw. 7. 
Łady Zabłockiego wydanego w 1845 roku w Petersburgu (na przykład wiersz pod tytułem Zdrowie Dymitra Demidowa), udało się wydrukować dzięki wsparciu Abbas Gulu Aga Bakichanowa, którego pracownikiem i przyjacielem w Azerbejdżanie był Tadeusz Łada-Zabłocki.

Cenzurze uległy również Szkice Kaukazu Ignacego Dobrskiego. Po usunięciu z utworu niektórych fragmentów zezwolono na wydanie pod warunkiem, że po po wydrukowaniu egzemplarze wyżej wymienionego utworu zostaną złożone w Komitecie Cenzury.

Jak widać, twórczość polskich poetów kaukaskich podlegała surowej cenzurze w Imperium Rosyjskim ze względu na ich przeszłość polityczną. Na Kaukazie obowiązywała potrójna cenzura, która składała się z cenzury literackiej, wojennej oraz kaukaskiej. Jej zadaniem było niedopuszczenie do druku utworów zawierających idee antyrządowe, kwestie wojenne oraz teksty odzwierciedlające interesy trzecich państw. Należy też dodać, że mimo iż w cenzurze carskiej czytano z potrójną czujnością twórczość „polskich poetów kaukaskich", to nie śledzono zbyt wnikliwie aluzji politycznych, czy języka ezopowego. Często dzięki temu były publikowane teksty niezgodne $\mathrm{z}$ interesami rządu carskiego. Utwory niezawierające poglądów politycznych zezwalano drukować i takie utwory dość szybko pojawiali się na łamach znanych rosyjskich i polskich gazet i czasopism oraz wydawnictw. Niektóre zaś utwory „oczyszczano” od „szkodliwych dla władzy informacji i poglądów”. Szczególnie „niebezpieczne” utwory jednak zakazywano drukować. Z tego właśnie względu większość utworów „polskich poetów kaukaskich” pozostała w rękopisach. Nie mniej ważne znaczenie odgrywały też kontakty osobiste, dzięki którym zezwalano na druk nawet potencjalnie „,niebezpieczne” utwory polskich zesłańców na Kaukazie. 


\section{Bibliografia}

Dondokowc, Ponurowskij J., Cenzura pieczati w Rossijskoj impierii, „Wiestnik CZITGU" 201, 1 №6 (73).

Filina M., Ossowska D., Losy Polaków na Kaukazie, Wydawnictwo „Universal”, Tbilisi 2015.

List Andrzejkowicza do J. I. Kraszewskiego, rkps BJ, sygn. 6460/IV.

Listy Marcina Szymanowskiego do Adama Zawadzkiego, Lietuvos Valstybes Istorijos Archyvas, zespół 1135, nr inw. 7.

Łada-Zabłocki T., Zdrowie Dymitra Demidowa improwizacja, [w:] Poezje Tadeusza Łady-Zabłockiego, Drukarnia Karola Kraja, Petersburg 1843.

Prokofjewad., Ob odnom stichotworienii Tadieusza Łady-Zabłockogo, „Sowietskoje sławianowiedienije" 1976, nr 4.

Sattarov S., Orient w twórczości „polskich poetów kaukaskich” (na przykładzie twórczości Tadeusza Łady-Zabłockiego, Władysława Strzelnickiego, Michała Butowta-Andrzejkowicza), „Tematy i Konteksty” 2019, Nr 9 (14). 